\title{
Pemanfaatan Tanaman Rosella (Hibiscus sadbariffa L.) sebagai Upaya dalam Meningkatkan Kesejahteraan dan Ekonomi Masyarakat Desa Sumberdem, Wonosari, Malang
}

\author{
Pujiyono*), Rifqi Dhiya Fauzan, Aam Yulianto, Arip Nur Usman, Ahmad Fauzi \\ Universitas Sebelas Maret \\ Jalan Ir. Sutami 36 Kentingan Surakarta \\ *pujifhuns@gmail.com
}

\begin{abstract}
Abstrak
Bunga rosella dipercaya memiliki manfaat kesehatan yang cukup tinggi dan memiliki rasa yang unik. Dalam berbagai penelitian, bunga rosella dapat menyembuhkan berbagai macam penyakit dan mencegah berbagai penularan penyakit serta dapat digunakan sebagai pewarna dan pengawet alami pada makanan atau minuman. Namun, cara budidaya tanaman rosella sangat berpengaruh pada khasiat atau kualitas dan kuantitas dari produk yang dihasilkan. Sehingga diperlukan pemahaman tentang budidaya tanaman rosella kepada masyarakat. Saat ini di pasaran sudah banyak beredar produk teh bunga rosella, namun pemanfaatannya sangat terbatas. Tujuan yang ingin dicapai dalam kegiatan ini adalah agar masyarakat mengetahui cara budidaya tanaman rosella yang baik dan benar serta mengetahui cara pembuatan sirup bunga rosella. Kegiatan pengabdian sudah dilaksanakan dengan metode penyuluhan dengan penyampaian materi tentang budidaya tanaman rosella, berbagai produk olahan rosella, dan terkait izin produk rumah tangga (P-IRT) serta motivasi IKM sedangkan pada sesi kegiatan demo, disampaikan tentang bahan-bahan dan tata cara pembuatan sirup bunga rosella. Kegiatan yang sudah terlaksana ini bermanfaat untuk menambah pengetahuan dan keterampilan masyarakat khususnya ibu-ibu kelompok Dasawisma Rosella tentang budidaya tanaman rosella dan aplikasi tanaman rosella.
\end{abstract}

Kata Kunci: rosella, budidaya, aplikasi, sirup.

\section{A. Pendahuluan}

Desa Sumberdem di Kecamatan Wonosari Kabupaten Malang sedang merintis tanaman rosella untuk dijadikan salah satu produk unggulan desa. Tanaman rosella saat ini sedang berkembang di masyarakat, karena banyak dimanfaatkan, terutama pada bagian bunganya. Bunga rosella dipercaya memiliki manfaat kesehatan yang cukup tinggi dan memiliki rasa yang unik. Dalam berbagai penelitian, bunga rosella dapat menyembuhkan berbagai macam penyakit dan mencegah berbagai penularan penyakit serta dapat digunakan sebagai pewarna dan pengawet alami pada makanan atau minuman. Warna merah pada bunga rosella (Hibiscus Sabdariffa L.) disebabkan oleh kandungan antosianin. Antosianin berfungsi sebagai antioksidan yang diyakini dapat menyembuhkan penyakit degeneratif. Antosianin memiliki sistem ikatan rangkap terkonjugasi yang menjadikan antosianin sebagai antioksidan dengan mekanisme penangkapan radikal (Mardiah et al., 2009).

Selain kaya akan manfaat, tanaman rosella juga memiliki budidaya yang mudah dan tidak memerlukan lahan yang luas. Namun pemahaman tentang budidaya tanaman rosella kepada masyarakat dinilai sangat penting. Menurut Wijayanti (2010), budidaya tanaman sangat berpengaruh terhadap khasiat atau kualitas dari produk tanaman yang diperoleh dan kuantitas produk yang dihasilkan. Jika penanganan pada saat panen dan pasca panen hingga 
pada pengolahannya tidak benar maka kualitas produk yang dihasilkan kurang berkhasiat atau kemungkinan juga dapat menimbulkan racun apabila dikonsumsi tidak sesuai dosis.

Pemanfaatan bunga rosella saat ini sudah banyak dilakukan oleh masyarakat. Walaupun saat ini di pasaran sudah banyak beredar produk teh bunga rosella, namun pemanfaatannya sangat terbatas. Bunga rosella yang sudah dipanen lalu diolah oleh masyarakat menjadi minuman sari bunga rosella. Minuman sari bunga rosella ini berencana akan segera dipasarkan ke berbagai penjuru daerah. Namun sayangnya produk minuman ini memiliki beberapa kelemahan, salah satunya yaitu memiliki umur simpan yang pendek. Minuman sari bunga rosella hanya mampu bertahan 2-3 hari pada suhu kamar, dan 7-8 hari pada suhu refrigerator (dingin).

Tujuan yang ingin dicapai pada kegiatan ini adalah sebagai berikut:

1. Masyarakat mengetahui cara budidaya tanaman rosella yang baik dan benar, terutama saat memasuki musim kemarau ataupun penghujan.

2. Masyarakat belum mengetahui cara pembuatan sirup bunga rosella.

Maka dari itu, melalui kegiatan pengabdian yang telah dilakukan ini, tim KKN UNS berupaya melakukan sosialisasi kepada masyarakat terkait budidaya dan aplikasi tanaman rosella untuk meningkatkan kesejahteraan dan ekonomi masyarakat Desa Sumberdem, Kecamatan Wonosari, Kabupaten Malang.

\section{B. Metode Pelaksanaan}

Kegiatan pengabdian ini dilakukan di Desa Sumberdem, Wonosari, Kabupaten malang, jawa Timur dalam rangka pelaksanaan Kuliah Kerja Nyata periode 2019. Masyarakat Sumberdem rata-rata memiliki lahan luas yang berada di daerah dataran tinggi. Lokasi yang luas selain ditanami kopi juga ditanami tanaman rosella. Hanya saja tanaman Rosella baru sebatas sebagai tanaman hias, oleh karena itu dilakukan pelatihan tentang budidaya dan aplikasi tanaman rosella untuk sebagai sumber ekonomi.

Metode kegiatan pengabdian dilakukan dengan mengadakan pelatihan kepada masyarakat yang difasilitasi oleh Ibu Lurah Sumberdem dengan menggunakan bahan dan peralatan yang sederhana. Tahapan kegiatan pengabdian yaitu sebagai berikut:

1. Pemberian materi kepada peserta tentang tata cara pembuatan sirup dari bunga Rosella home made secara mudah dan sederhana. Pemberian materi ini dilakukan dengan melakukan penjelasan dan pemutaran video.

2. Pelatihan pembuatanan sirup dari bunga Rosella dilakukan dengan demonstrasi dan praktek secara langsung. Peserta melihat secara langsung cara pembuatannya.

\section{Hasil dan Pembahasan}

\section{Rosella dan kandungan manfaatnya}

Rosella (Hibiscus sadbariffa L.) merupakan anggota famili Malvaceae. Rosella dapat tumbuh baik di daerah beriklim tropis dan subtropis. Tanaman ini mempunyai habitat asli di daerah yang terbentang dari India hingga Malaysia. Sekarang, tanaman ini tersebar luas di daerah tropis dan subtropis di seluruh dunia dan mempunyai nama umum yang berbeda-beda di berbagai negara (Maryani dan Kristiana, 2008). Berikut adalah klasifikasi tanaman rosella (BPOM, 2010):

Kingdom : Plantae 


$\begin{array}{ll}\text { Divisi } & \text { : Magnoliophyta } \\ \text { Kelas } & \text { : Magnoliopsida } \\ \text { Subkelas } & \text { : Dilleniidae } \\ \text { Bangsa } & \text { : Malvales } \\ \text { Suku } & \text { : Malvaceae } \\ \text { Marga } & \text { : Hibiscus } \\ \text { Jenis } & \text { : Hibiscus sabdariffa Linn }\end{array}$

Tanaman rosella hidup berupa semak yang berdiri tegak dengan tinggi 0,5-5 meter, memiliki batang yang berbentuk silindris dan berkayu, serta memiliki banyak percabangan. Ketika masih muda, batangnya berwarna hijau. Dan ketika beranjak dewasa dan sudah berbunga, batang rosella berwarna cokelat kemerahan. Pada batang rosella melekat daundaun yang tersusun, berwarna hijau, berbentuk bulat telur dengan pertulangan menjari dan tepi beringgit. Ujung daun rosella meruncing dan tulang daunnya berwarna merah. Panjang daun rosella dapat mencapai $6-15 \mathrm{~cm}$ dan lebar $5-8 \mathrm{~cm}$. Akar yang menopang batangnya berupa akar tunggang. Mahkota bunganya berbentuk corong yang tersusun dari 5 helai daun mahkota (Widyanto dan Nelistya, 2009).

Antosianin merupakan golongan senyawa kimia organik yang dapat larut dalam pelarut polar, serta bertanggung jawab dalam memberikan warna oranye, merah, ungu, biru, hingga hitam pada tumbuhan tingkat tinggi seperti: bunga, buah-buahan, biji-bijian, sayuran, dan umbi-umbian (Du et all., 2015). Antosianin yang merupakan zat warna alami golongan flavonoid dengan tiga atom karbon yang diikat oleh sebuah atom oksigen untuk menghubungkan dua cincin aromatik benzene $\left(\mathrm{C}_{6} \mathrm{H}_{6}\right)$ di dalam struktur utamanya (Hambali $d k k, 2014)$. Antosianin mempunyai karakteristik kerangka karbon $\left(\mathrm{C}_{6} \mathrm{C}_{3} \mathrm{C}_{6}\right)$ dengan struktur dasar antosianin adalah 2-fenil-benzofirilium dari garam flavilium (Santoso \& Estiasih, 2014).

Keberadaan antosianin pada tanaman terletak di dalam sel vakuola dari tanaman itu sendiri, sehingga kebanyakan antosianin ditemukan dan dapat diambil dari beberapa organ tanaman, seperti mahkota bunga, daun, buah, biji-bijian, hingga pada umbi-umbian. Warna antosianin bukanlah sebagai pembeda saja, tetapi juga merupakan informasi penting mengenai kandungan nutrisinya. Semakin pekat atau kuat warna yang dihasilkan pada tanaman menunjukkan bahwa semakin besar pula konsentrasi antosianin yang terdapat pada tanaman tersebut (Priska $d k k, 2018$ ).

Antosianin yang terdapat pada bunga, khususnya pada mahkota bunga kebanyakan ditemukan pada bunga dengan konsentrasi antosianin yang bervariasi: mawar $(0,925 \% / 10$ g), kembang sepatu $(0,739 \% / 10 \mathrm{~g})$, rosela $(0,795 \% / 10 \mathrm{~g}$ berat bunga segar, $44,856 \% / 100 \mathrm{~g}$ berat kering), pukul empat $(0,977 \% / 10$ gr), dan lain-lain (Djaeni $d k k, 2017)$. Fungsi antioksidan dari antosianin memiliki berbagai macam manfaat dalam mencegah berbagai penyakit degeneratif, salah satunya yaitu pencegahan penyakit kardiovaskuler (Wallace, 2011).

\section{Pembuatan Sirup Rosella}

Sirup merupakan larutan gula pekat (sakarosa : high fructosa syrup dan atau gula invert lainnya) dengan atau tanpa penambahan tambahan makanan yang diizinkan. Sirup memiliki kadar kekentalan yang cukup tinggi serta kadar gula dalam sirup antara 55 - $65 \%$ menyebabkan pengenceran sangat perlu dilakukan jika ingin mengkonsumsi sirup. 
Pembuatan sirup dapat ditambahkan pewarna dan asam sitrat untuk menambah warna dan cita rasa (Satuhu, 2004).

Pada pembuatan sirup, pengendapan sering kali terjadi akibatnya sirup menjadi cair dibagian atas namun dibagian bawah tetap kental. Masalah ini dapat diatasi dengan cara penambahan bahan penstabil yang berfungsi mempertahankan kestabilan suspensi agar partikel padatannya tetap terdispersi merata keseluruh bagian medium pendispersi, selain itu bahan penstabil berfungsi untuk meningkatkan viskositas, memperbaiki warna, cita rasa, dan konsistensi sirup buah. Sifat setiap zat penstabil untuk dapat menstabilkan berbeda-beda, tergantung keadaan bahan yang akan distabilkan (Haryoto, 2001).

Sirup terdiri dari bahan-bahan utama seperti bahan pengental, pengawet dan cita rasa. Sari dari bahan yang dipergunakan adalah cairan buah atau sayur yang tidak mengalami fermentasi. Untuk mendapatkan sari buah yang baik, sari perlu dipisahkan dari bagianbagian yang tidak larut dengan penyaringan. Kadar gula dalam sirup yang cukup tinggi, dimaksudkan untuk mencegah pertumbuhan mikroorganisme (bakteri ragi dan jamur) yang mungkin terdapat dalam sirup (Winarno, 2007).

Kegiatan pengabdian sudah dilaksanakan dengan metode penyuluhan dengan penyampaian materi tentang budidaya tanaman rosella, berbagai produk olahan rosella, dan terkait izin produk rumah tangga (P-IRT) serta motivasi IKM (Industri Kecil Mikro). Setelah itu dilanjutkan keesokan harinya yaitu demo pembuatan sirup bunga rosella.

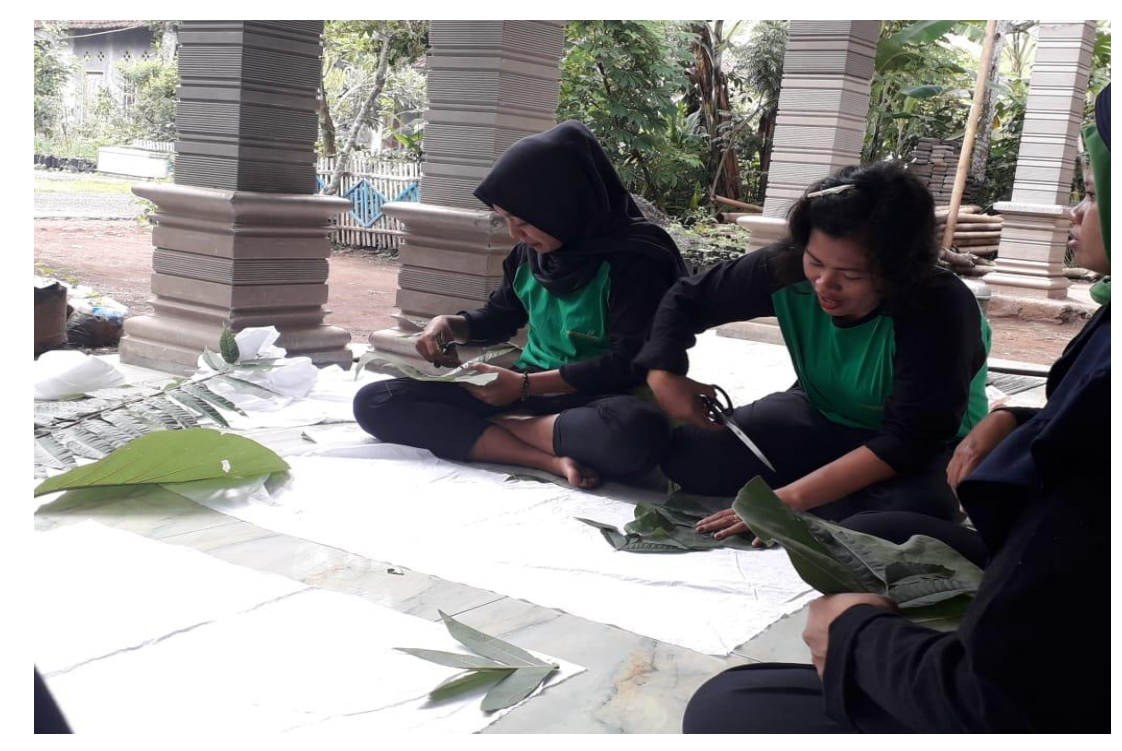


Jurnal SEMAR Vol. 10 No. 1, hal. $22-28$ elSSN: 2745-4223 | Copyright (C LPPM Universitas Sebelas Maret Homepage: https://jurnal.uns.ac.id/jurnal-semar
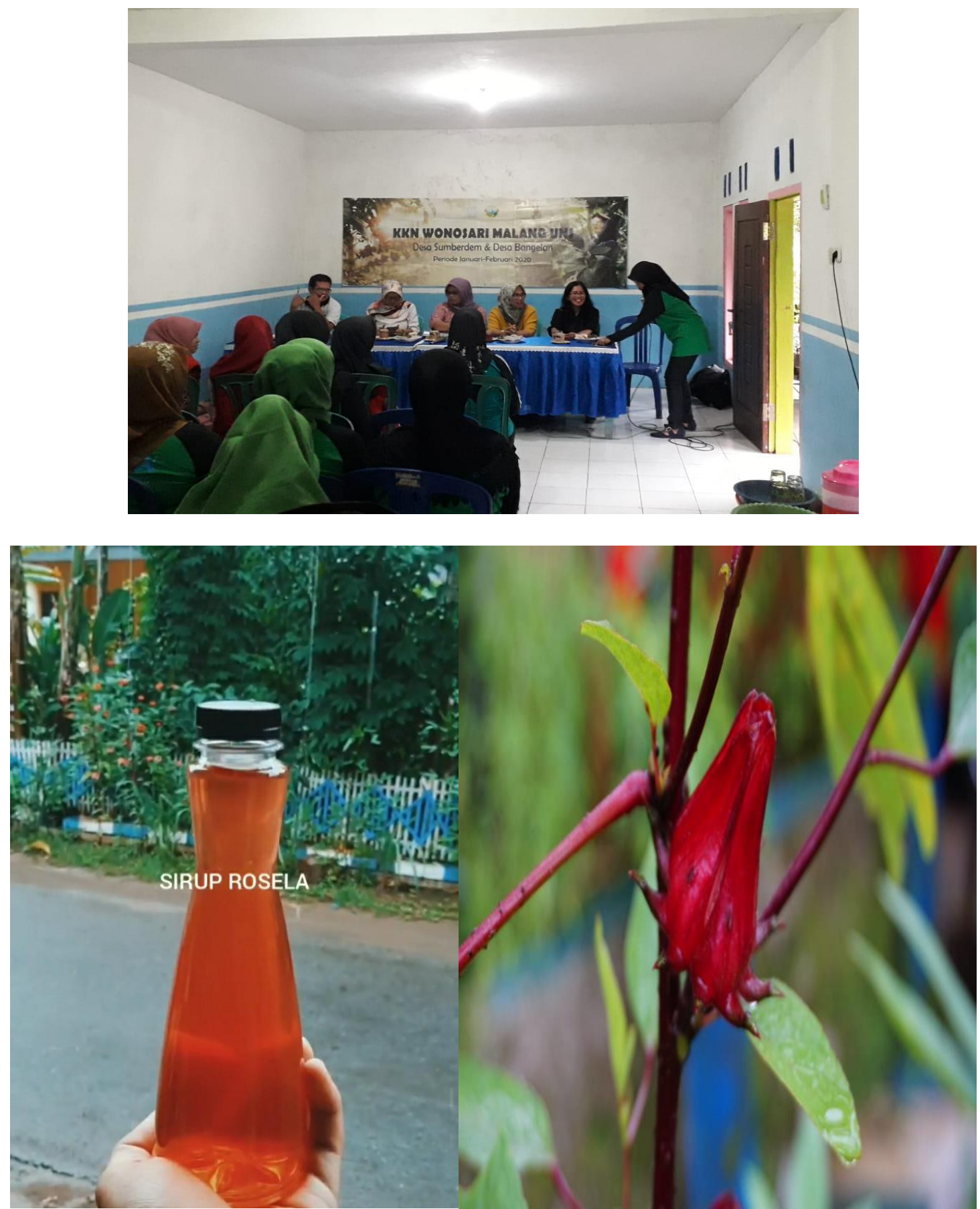

Gambar 1. Pelaksanaan kegiatan pengabdian

Kegiatan yang dilakukan berdampak pada semakin tingginya tingkat pemahaman masyarakat, khususnya ibu-ibu kelompok Dasawisma Rosella Sumberdem Malang tentang bagaimana cara budidaya tanaman rosella yang baik dan benar, terutama saat memasuki musim penghujan ataupun kemarau. Kegiatan diskusi berlangsung kondusif dan peserta sosisalisasi proaktif dalam tanya jawab. Pada sesi kegiatan demo, disampaikan tentang bahan-bahan dan tata cara pembuatan sirup bunga rosella. Sirup bunga rosella merupakan 
salah satu produk olahan rosella yang terbuat dari beberapa bahan yang sederhana dan mudah didapat, selain itu bahan-bahan pembuatan sirup rosella juga tergolong hemat. Bahan utama pembuatan sirup rosella yaitu bunga rosella yang sudah dihilangkan bijinya dan gula pasir. Gula pasir dapat berfungsi sebagai pembentuk tekstur dan rasa pada sirup, serta dapat meningkatkan umur simpan pada sirup. Bahan lain yang dapat ditambahkan yaitu air mineral dan Carboxymethyl Cellulose (CMC) yang berfungsi sebagai pengental pada sirup. Pada demo pembuatan sirup rosella juga dijelaskan bagaimana tata cara penyimpanan sirup yang baik dan benar. Sirup sebaiknya disimpan diwadah yang tertutup rapat dan terhindar dari sinar matahari langsung. Dan agar sirup lebih awet, simpan didalam refrigerator (suhu dingin) agar terhindar dari pertumbuhan jamur.

Hingga saat ini, sirup rosella masih belum banyak diketahui oleh masyarakat, karena keterbatasan pengetahuan dan daya saing sirup komersil yang semakin banyak diminati. Oleh karena itu, dengan hadirnya sirup bunga rosella diharapkan dapat meningkatkan perekonomian dan kesejahteraan masyarakat Desa Sumberdem dengan membuat suatu merk produk sirup rosella lokal. Rasa sirup rosella tidak berbeda jauh dengan minuman sari bunga rosella. rasa masam bercampur manis menjadikan ciri khas dari produk olahan bunga rosella.

\section{Kesimpulan}

Kegiatan Sosialisasi dan Demo yang telah dilaksanakan di Desa Sumberdem, Kecamatan Wonosari, Kabupaten Malang bermanfaat untuk menambah pengetahuan dan keterampilan masyarakat khususnya ibu-ibu kelompok Dasawisma Rosella tentang budidaya tanaman rosella dan aplikasi tanaman rosella, serta cara pembuatan sirup rosella.

\section{Ucapan terima Kasih}

Penulis mengucapkan terima kasih kepada Ketua Lembaga Penelitian dan Pengabdian (LPPM) Universitas Sebelas maret, Bapak Kepala UP KKN LPPM UNS, Ibu Lurah Sumberdem, Wonosari, malang dan seluruh masyarakat Sumberdem atas segala bentuk bantuan dan partisipasinya selama kegiatan KKN.

\section{DAFTAR PUSTAKA}

BPOM RI. 2010. Serial Data Ilmiah Terkini Tumbuhan Obat : Rosella (Hibiscuss sabdariffa L. ). Direktorat Obat Asli Indonesia. BPOM RI. Hlm 2

Djaeni, M., Ariani, A., Hidayat, R., \& Utari, F. D. 2017. Ekstraksi Antosianin dari Kelopak Bunga Rosella (Hibiscus sabdariffa L.) Berbantu Ultrasonik: Tinjauan Aktivitas Antioksidan. Jurnal Aplikasi Teknologi Pangan 6 (3): 148 - 151.

Du, H., et. all. 2015. Methylation Mediated by An Anthocyanin, O-Methyltransferase, Is Involved in Purple Flower Coloration in Paeonia. Journal of Experimental Botany 66 (21): 6563 - 6577.

Hambali, M., Mayasari, F., \& Noermansyah, F. 2014. Ekstraksi Antosianin dari Ubi Jalar dengan Variasi Konsentrasi Solven, dan Lama Waktu Ekstraksi. Teknik Kimia 20 (2): $25-35$.

Haryoto, 2001. Teknologi Tepat Guna Sirup Sirsak. Yogyakarta : Kanisius.

Mardiah, dkk. 2009. Budidaya dan Pengolahan Rosella Si Merah Segudang Manfaat. Jakarta: Agromedia Pustaka 
Jurnal SEMAR Vol. 10 No. 1, hal. $22-28$ elSSN: 2745-4223 | Copyright @ LPPM Universitas Sebelas Maret Homepage: https://jurnal.uns.ac.id/jurnal-semar

Maryani, Herti dan Kristiana, Lusi. 2008. Khasiat dan Manfaat Rosela rev. Jakarta: PT. AgroMedia Pustaka

Priska, Melania dkk. 2018. Review : Antosianin dan Pemanfaatannya. Cakra Kimia (Indonesian E-Journal of Applied Chemistry) Vol. 6 No.2 (5-8).

Santoso, W. E. A., \& Estiasih, T. 2014. Kopigmentasi Ubi Jalar Ungu (Ipomoea batatas var. Ayamurasaki) dengan Kopigmen Na-Kaseinat dan Protein Whey serta Stabilitasnya terhadap Pemanasan. Jurnal Pangan dan Agroindustri 2 (4): 121 - 127.

Satuhu, S. 2004. Penanganan dan Pengolahan Buah. Jakarta: Penebar Swadaya.

Wallace, T. C. 2011. Anthocyanins in Cardiovascular Disease. American Society for Nutrition. Adv. Nutr. 2: 1 - 7. DOI: 10.3945/an.110.000042.

Widyanto, Poppy dan A. Nelistya. 2009. Rosella Aneka Olahan, Khasiat dan Ramuan. Depok : Penebar Swadaya.

Winarno, F.G. 2007. Kimia Pangan dan Gizi. Jakarta : Gramedia Pustaka Utama. 